\title{
URGENSI PENERAPAN KEPATUHAN SYARIAH PADA PERBANKAN SYARIAH (Telaah Konseptual-Analitis)
}

\author{
Wulpiah \\ STAIN Syaikh Abdurrahman Siddik Bangka Belitung
}

\begin{abstract}
The issue of shariah compliance is increasingly important, given that Islamic finance is always challenged by demand from market participants to be innovative and business oriented (eg. offering new instruments and products), as conventional financial does. This fact can encourage the Islamic financial position further improve. On the one hand they should accommodate the demand of customers that may be contrary to shariah principles, but on the other hand Islamic banks are strictly bound by shariah compliance. This paper will focus on the importance of applying aspects of shariah compliance in Islamic banking.

In various opinions, the meaning of shariah compliance in Islamic banks is "the application of Islamic principles, shariah and traditions in financial transactions and banking and other related business". Shariah is one of the indicators of Islamic disclosure to ensure the adherence of Islamic banks to shariah principles. Furthermore, at the operational level, shariah compliance is compliance to the Dewan Syariah Nasional which is the embodiment of shariah principles and rules that must be adhered in Islamic banking.

Some provisions that can be used to assess shariah compliance within Islamic financial institutions are: First, contract used for the collection and distribution of funds in accordance with the priciples of shariah and the rules of shariah. Second, Zakat funds is calculated and paid, managed in accordance with the rules and principles of shariah. Third, All transactions and economic activities are reported fairy in accordance with applicable shariah accounting standards. Fourth, the work environment and corporate culture in accordance with shariah. Fift, business that are financed do not conflict with shariah. Sixthly, there is Shariah Supervisory Board (DPS) as a shariah director for the overall operational activities of Islamic banks. Seventh, the source of funds comes from a legitimate and lawful source according to shariah.

Related to the implementation mechanisme of shariah compliance, there are two underlying concept both in the context of the fulfillment of accuntability horizontally and transcendental. First, The concept of shariah review must be done by DPS to conduct supervision on shariah compliance. Second, the concept of shariah internal review, Islamic banking as one of internal audit function. If the optimazation of the implementation of shariah compliance aspect in Islamic banking is a necessity, so that
\end{abstract}


the impact of Islamic bank can be the only option for the society to save and do the financing.

\section{Kata Kunci: Sharia Compliance, Sharia Banking}

\section{A. PENDAHULUAN}

Salah satu pilar penting dalam pengembangan bank syariah adalah syariah compliance. Pilar inilah yang menjadi pembeda utama antara bank syariah dengan bank konvensional. Untuk menjamin teraplikasinya prinsip-prinsip syariah di lembaga perbankan, diperlukan pengawasan syariah yang diperankan oleh Dewan Pengawas Syariah (DPS). Dalam pokok-pokok hasil penelitian Bank Indonesia menyatakan bahwa nasabah yang menggunakan jasa bank syariah, sebagian memiliki kecenderungan untuk berhenti menjadi nasabah antara lain karena keraguan akan konsistensi penerapan prinsip syariah.

Kepatuhan dan kesesuaian bank syariah terhadap prinsip syariah sering dipertanyakan oleh para nasabah. Secara implisit menunjukkan bahwa praktik perbankan syariah selama ini kurang memperhatikan prinsip-prinsip syariah, salah satu penyebab kepercayaan masyarakat pada bank syariah hal ini juga akan berdampak pada loyalitas masyarakat menggunakan jasa bank syariah. Peningkatan kepercayaan nasabah dapat digunakan sebagai indikator keberhasilan perkembangan bank syariah dan sekaligus sebagai prediksi keberhasilan bank syariah. Karenanya kepatuhan syariah merupakan pemenuhan terhadap prinsip syariah dalam sistem kerja yang dilakukan sebagai wujud dari karakteristik lembaga itu sendiri, terutama lembaga bank syariah. Dari sudut pandang masyarakat, khususnya pengguna jasa bank syariah; kepatuhan syariah merupakan inti dari integritas dan kredibilitas bank syariah. Mengingat keyakinan dan kepercayaan masyarakat kepada 
bank syariah didasarkan dan dipertahankan melalui pelaksanaan prinsip hukum Islam yang diadaptasi dari aturan operasionalisasi institusi tersebut. Sebab ketidakpatuhan terhadap prinsip syariah akan berdampak negatif citra bank syariah dan berpotensi untuk ditinggalkan oleh nasabah potensial dan pengguna jasa bank syariah. (Undangundang Nomor 21 Tahun 2008 tentang Perbankan Syariah).

Laporan atau opini Dewan Pengawas Syariah yang selalu dilampirkan dalam laporan keuangan bank syariah seakan-akan belum mampu menjawab kritikan dan rasa penasaran masyarakat tentang sejauh mana praktek perbankan syariah di Indonesia saat ini apakah telah sesuai syariah? Sehingga informasi tentang kepatuhan syariah (shariah compliance) seakan-akan menjadi misteri bagi masyarakat yang menyebabkan semakin runcingnya perdebatan tentang aspek kepatuhan syariah di bank syariah saat ini. Apalagi masing-masing pihak yang berdebat memiliki dasar hukum sendiri-sendiri, seakan-akan hanya manajemen bank syariah dan Dewan Pengawas Syariah serta Bank Indonesia semata saja yang bisa mengetahui tingkat kepatuhan syariah di bank syariah.

Tulisan ini mencoba mengkaji kembali tentang pentingnya mengaplikasikan kepatuhan syariah dalam sistem operasional bank syariah, hal ini dilakukan untuk meminimalisir adanya bank syariah yang belum sepenuhnya syar'i. Mengingat salah satu indikator bank syariah itu telah menerapkan prinsip-prinsip syariah adalah totalitas dalam menerapkan kepatuhan syariah.

\section{B. PEMBAHASAN}

\section{Urgensi Kepatuhan Syariah}

Shariah compliance merupakan key player dalam pelaksanaan Good Corporate Governance (GCG) pada industri perbankan syariah. 
Sebagaimana tertuang dalam Peraturan Bank Indonesia No. 11/33/PBI/2009 tentang Pelaksanaan Good Corporate Governance Bagi Bank Umum Syariah Dan Unit Usaha Syariah, bahwa pelaksanaan GCG dalam industri perbankan syariah harus memenuhi prinsipprinsip syariah. Pentingnya pelaksanaan GCG merupakan salah satu upaya untuk melindungi kepentingan stakeholders, meningkatkan kepatuhan terhadap peraturan perundang-undangan yang berlaku serta nilai-nilai etika yang berlaku secara umum pada industri perbankan syariah. Sebagai sebuah ladang kepercayaan bagi para stakeholders, maka sejatinya aturan main dalam perbankan syariah sudah menjadi keharusan agar setiap tindakan operasional senantiasa sesuai dengan prinsip-prinsip syariah itu sendiri. Dengan demikian hal ini semestinya menjadi kewajiban tersendiri bagi perbankan syariah untuk melaporkan pelaksanaan shariah compliance dalam operasionalnya. Namun tentunya untuk menghasilkan pelaporan yang sistematis dan dimengerti oleh semua pihak yang membutuhkan informasi, perlu adanya sebuah standar bagi pelaksanaan GCG dan standar akuntansi bagi perbankan syariah, (Dedhi Ana dan Ahmad Tarmizi Lubis, 2014)

Kepatuhan syariah (syariah compliance) saat ini menjadi isu penting bagi stakeholders bank syariah di Indonesia. Banyak kritikan tajam dari masyarakat tentang kepatuhan bank syariah terhadap prinsip-prinsip syariah, bahwa bank syariah di Indonesia saat ini kurang sesuai syariah. Kondisi tersebut boleh jadi sebagai dampak positif dari semakin masifnya sosialisasi tentang perbankan syariah ke masyarakat sehingga masyarakat mulai sadar dan memiliki pengetahuan yang cukup tentang perbankan syariah. Kritikan tajam 
mulai muncul ketika masyarakat merasa bahwa terjadi perbedaan antara teori dan praktek. (Muhamad, 2010)

Jika diperhatikan lebih jeli, masyarakat umum para stakeholders bank syariah di Indonesia bisa mengetahui dan mengukur serta menilai sejauhmana operasional bank syariah sesuai dengan prinsip-prinsip syariah yaitu melalui laporan keuangan bank syariah yang senantiasa dipublikasikan secara periodik. Sesuai dengan tujuan penyusunan laporan keuangan syariah yang dinyatakan dalam Pernyataan Standar Akuntansi Keuangan (PSAK) Syariah dalam Kerangka Dasar Penyusunan dan Penyajian Laporan Keuangan Syariah paragraf $\mathbf{3 0}$ menyatakan bahwa tujuan laporan keuangan syariah adalah meningkatkan kepatuhan terhadap prinsip syariah dalam semua transaksi dan kegiatan usaha entitas syariah.

PSAK Syariah telah mengidentifikasi ada 12 ciri/karakteristik transaksi syariah dalam Kerangka Dasar Penyusunan dan Penyajian Laporan Keuangan Syariah paragraf 27 yang harus tercermin dalam laporan keuangan syariah di bank syariah sebagai entitas syariah. Dari kedua belas ciri tersebut paling tidak ada ada tiga ciri yang bisa dianalisis langsung dalam laporan keuangan syariah oleh masyarakat yaitu tidak mengandung unsur riba, tidak mengandung unsur gharar, tidak mengandung unsur haram, dan tidak menganut prinsip nilai waktu uang (time value of money) (Muhammad, 2013).

Untuk mengidentifikasi ada tidaknya bunga dan pendapatan haram lainnya, maka bisa dianalisis sumber-sumber pendapatan yang diperoleh bank syariah. Sumber pendapatan yang harus diperhatikan adalah sumber pendapatan bunga yang berasal dari penempatan dana bank syariah di bank konvensional. Berdasarkan PSAK Syariah maka pendapatan bunga dan denda tidak boleh diakui 
sebagai pendapatan bank syariah, tetapi harus diakui sebagai pendapatan dana kebajikan. Beberapa penelitian menunjukkan bahwa bank umum syariah yang ada saat ini, masih ada salah satu bank syariah yang mengakui adanya pendapatan bunga dari penempatan dananya dibank konvensional sebagai pendapatan utama, bahkan termasuk komponen yang dibagi hasilkan kepada nasabah deposan. Atas kejadian tersebut belum ada pengungkapan informasi dari Dewan Pengawas Syariah dan Bank Indonesia, mengapa hal tersebut masih dikatakan sesuai syariah dalam opini DPS bank syariah yang bersangkutan yang dilampirkan dalam publikasi laporan keuangan.

Identifikasi apakah dalam bank syariah terdapat unsur time value of money dapat dilihat dalam catatan atas laporan keuangan tentang metode akuntansi yang digunakan dalam pengakuan pendapatan margin murabahah. Berdasarkan PSAK Syariah 102 tentang akuntansi murabahah paragraf 23 sampai dengan 25 menyebutkan bahwa pengakuan pendapatan margin murabahah yang diperkenankan adalah secara proporsional. Dari beberapa literatur menjelaskan masih banyak bank syariah yang menggunakan metode anuitas dalam pengakuan pendapatan margin murabahah. Metode anuitas akan menguntungkan bagi bank syariah karena margin murabahah diakui diawal lebih besar dan akan menurun terus sampai pada angsuran terakhir. Sehingga jika metode anuitas masih digunakan dalam pengakuan pendapatan margin murabahah, maka bank syariah masih memegang prinsip-prinsip time value of money.

Ada atau tidaknya unsur gharar dalam bank syariah bisa diukur dan dianalisis dari laporan rekonsiliasi pendapatan dan bagi hasil. Pendapatan yang dibagi hasilkan oleh bank syariah harus bersifat cash basis tidak boleh pendapatan accrual. Ada beberapa bank 
yang tidak menyajikan laporan rekonsiliasi pendapatan dan bagi hasil sehingga tidak bisa diketahui apakah pendapatan yang dibagi hasilkan ke nasabah deposan adalah yang riil ataukah masih accrual. Teknik kedua adalah dengan melihat pengukuran pendapatan yang dibagi hasilkan apakah menggunakan metode revenue sharing atau gross profit sharing? Jika bank syariah masih menggunakan revenue sharing maka masih ada unsur kezhaliman. Berdasarkan Fatwa DSN No.15 Tahun 2000 sistem distribusi bagi hasil yang diperbolehkan adalah gross profit sharing atau profit loss sharing.

Oleh karena itu, penting untuk dilakukan pengawasan fungsi kepatuhan syariah di industri keuangan syariah, dimana fungsi kepatuhan merupakan tindakan dan langkah yang bersifat ex-ante (preventif), untuk memastikan kebijakan, ketentuan, sistem dan prosedur, serta kegiatan usaha yang dilakukan oleh Bank Islam sesuai dengan ketentuan Bank Indonesia, Fatwa DSN dan peraturan perundang-undangan yang berlaku. Hal ini dilakukan untuk mengontrol operasional perbankan syariah serta menjadikan bank syariah agar tidak keluar dari koridornya, disiplin dan langkah untuk meminimalisir resiko perbankan.

\section{Pengertian Kepatuhan Syariah}

Shariah compliance adalah ketaatan bank syariah terhadap prinsip-prinsip syariah. Bank syariah merupakan lembaga keuangan yang beroperasi sesuai dengan prinsip-prinsip syariah Islam, artinya bank dalam beroperasinya mengikuti ketentuan-ketentuan syariah Islam khususnya menyangkut tata-cara bermuamalat secara Islam. Prinsip utama bank syariah tercermin dalam produk-produk yang 
dihasilkannya bebas bunga dengan menggunakan prinsip bagi hasil. (Syafii Antonio, 2001).

Kepatuhan syariah juga merupakan bagian dari pelaksanaan framework manajemen resiko, dan mewujudkan budaya kepatuhan dalam mengelola resiko perbankan Islam. Kepatuhan syariah (shariah compliance) juga memiliki standar internasional yang disusun dan ditetapkan oleh Islamic Financial Service Board (IFSB) dimana kepatuhan syariah merupakan bagian dari tata kelola lembaga (corporate governance). Kepatuhan syariah merupakan manifestasi pemenuhan seluruh prinsip syariah dalam lembaga yang memiliki wujud karakteristik, integritas dan kredibilitas di bank syariah, di mana budaya kepatuhan tersebut adalah nilai, perilaku dan tindakan yang mendukung terciptanya kepatuhan bank syariah terhadap seluruh ketentuan Bank Indonesia. (BI, 20011)

Menurut Adrian Sutedi, kepatuhan syariah secara operasional adalah kepatuhan kepada Fatwa Dewan Syariah Nasional (DSN) karena Fatwa DSN merupakan perwujudan prinsip dan aturan syariah yang harus ditaati dalam perbankan syariah. dalam operasional bank syariah tidak hanya meliputi produk saja, akan tetapi meliputi sistem, teknik dan identitas perusahaan. Karena itu, budaya perusahaan yang meliputi pakaian, dekorasi dan image perusahaan merupakan salah satu aspek kepatuhan syariah dalam bank syariah. Tujuannya, tidak lain untuk menciptakan suatu moralitas dan spiritual kolektif, yang apabila digabungkan dengan produksi barang dan jasa, maka akan menopang kemajuan dan pertumbuhan jalan hidup yang islami. Kepatuhan syariah tersebut secara konsisten dijadikan sebagai kerangka kerja bagi sistem dan 
keuangan bank syariah dalam alokasi sumber daya, manajemen, produksi, aktivitas pasar modal dan distribusi kekayaan.

Menurut Arifin (2009) makna kepatuhan syariah (shariah compliance) dalam bank syariah adalah "penerapan prinsip-prinsip Islam, syariah dan tradisinya dalam transaksi keuangan dan perbankan serta bisnis lain yang terkait". Ansori (2001) mengemukakan bahwa shariah compliance adalah salah satu indikator pengungkapan islami untuk menjamin kepatuhan bank Islam terhadap prinsip syariah. Dalam ketentuan kepatuhan syariah yang dapat digunakan sebagai ukuran secara kualitatif untuk menilai ketaatan syariah di dalam lembaga keuangan syariah, antara lain:

1. Akad atau kontrak yang digunakan untuk pengumpulan dan penyaluran dana sesuai dengan prinsip-prinsip syariah dan aturan syariah yang berlaku.

2. Dana zakat dihitung dan dibayar serta dikelola sesuai dengan aturan dan prinsip-prinsip syariah.

3. Seluruh transaksi dan aktivitas ekonomi dilaporkan secara wajar sesuai dengan standar akuntansi syariah yang berlaku.

4. Lingkungan kerja dan corporate culture sesuai dengan syariah

5. Bisnis usaha yang dibiayai tidak bertentangan dengan syariah.

6. Terdapat Dewan Pengawas Syariah (DPS) sebagai pengarah syariah atas keseluruhan aktivitas operasional bank syariah.

7. Sumber dana berasal dari sumber yang sah dan halal menurut syariah. Mekanisme kepatuhan syariah terdapat dua konsep yang mendasari pelaksanaan pengawasan syariah dalam 
konteks pemenuhan akuntabilitas secara horizontal dan transendental. Pertama, konsep shariah review harus dilakukan oleh DPS untuk melakukan pengawasan terhadap kepatuhan syariah. Kedua, konsep internal shariah review bank syariah sebagai salah satu fungsi internal audit. DPS merupakan badan independen yang ditempatkan oleh DSN yang anggotanya terdiri dari para ahli bidang Fiqh Muamalah dan memiliki pengetahuan umum dalam bidang lembaga keuangan syariah (Ardhaningsih, 2012).

Kepatuhan syariah merupakan bagian dari sistem tata kelola perbankan syariah yang baik. Pengelolaan bank Syariah tidak bisa lepas dari pemenuhan prinsip-prinsip syariah, terutama dalam pelaksanaan fungsi intermediasi. Pada tataran operasional pengumpulan dan penyaluran dana masyarakat harus menerapkan prinsip-prinsip syariah. Kepatuhan syariah merupakan salah satu unsur dalam penilaian mengenai tingkat kesehatan bank Syariah. Pemeliharaan tingkat kesehatan bank akan berbanding lurus dengan pemeliharaan kepercayaan masyarakat, sehingga bila bank lalai dalam menjaga tingkat kesehatanannya karena tidak menerapkan prinsip syariah, maka kepercayaan masyarakat terhadap bank akan hilang. Dalam perspektif Perbankan Syariah, kepatuhan Syariah adalah meningkatkan pengetahuan syariah dan menciptakan inovasi produk dan layanan kreatif dengan tetap patuh pada aturan DSN. Peran DPS yang belum optimal dapat berdampak terhadap risk management. Jenis manajemen risiko yang terkait erat dengan peran DPS adalah risiko reputasi yang selanjutnya berdampak pada displaced commercial risk, seperti risiko likuiditas dan risiko lainnya. Langkah pengutan peran DPS dapat ditempuh melalui 
berbagai aspek di antaranya mempertegas kompetensi keilmuan DPS, mempertegas batasan maksimal jabatan DPS, dan evaluasi peran DPS pada bank Syariah oleh MUI dan BI. (Agus Waluyo, 2016)

Temuan menarik dari penelitian Chapra dan Ahmed (2002) juga menjelaskan sejumlah 288 nasabah (62\%) responden dari 463 nasabah yang terlibat dalam survei tata kelola (GCG) yang dilakukannya (berasal dari 14 bank syariah di Bahrain, Bangladesh dan Sudan) menjawab akan memindahkan dananya ke bank syariah yang lain jika ditengarai terjadi "pelanggaran syariah" dalam operasional bank syariah. Hal ini menunjukkan bahwa aspek kepatuhan terhadap prinsip syariah amat signifikan mempengaruhi perilaku nasabah dalam memilih bank syariah.

Secara umum, konsep dasar kepatuhan berfungsi sebagai pelaksana dan pengelola risiko kepatuhan yang berkoordinasi dengan satuan kerja dalam manajemen resiko. Fungsi kepatuhan melakukan tugas pengawasan yang bersifat preventif dan menjadi elemen penting dalam pengelolaan dan operasional bank syariah, pasar modal, asuransi syariah, pegadaian syariah serta lembaga keuangan syariah non bank (koperasi jasa keuangan syariah). Hal ini dilakukan untuk memastikan bahwa kebijakan, ketentuan, sistem dan prosedur yang dilakukan oleh perbankan Islam telah sesuai dengan ketentuan dan peraturan perundang-undangan Bank Indonesia, Pemerintah, Bapepam-LK, Fatwa MUI, serta penetapan hukum yang telah ditetapkan dalam standar internasional IFSB, AAOIFI, Syariah Supervisory Board (SSB).

IFSB adalah organisasi penetapan standar internasional, diresmikan tanggal 3 November 2002 dan mulai beroperasi pada tanggal 10 Maret 2003. Organisasi ini mempromosikan, 
meningkatkan performance dan stabilitas industri jasa keuangan Islam dengan menerbitkan standar global prinsip kehati-hatian dan panduan bagi industri secara luas yang mencakup perbankan, pasar modal dan sektor asuransi. Standar disusun oleh IFSB mengikuti proses hukum yang dituangkan dalam Pedoman dan Tata Cara Penyusunan standar/Pedoman, yang meliputi penerbitan draft paparan dan penyelenggaraan lokakarya dan, jika diperlukan, dengar pendapat publik. IFSB juga melakukan inisiatif penelitian dan koordinat pada industri-isu terkait, serta round tables, seminar dan konferensi bagi regulator dan pemangku kepentingan industri, Islamic Financial Service Board (IFSB), Guiding Principles on Shariah Governance Systems for Institutions Offering Islamic Financial Services, kredibilitas di bank syariah. Budaya kepatuhan tersebut adalah nilai, perilaku dan tindakan yang mendukung terciptanya kepatuhan bank syariah terhadap seluruh ketentuan Bank Indonesia. Elemen yang memiliki otoritas dan wewenang dalam melakukan pengawasan terhadap kepatuhan syariah adalah Dewan Pengawas Syariah (DPS). Dewan Pengawas Syariah melengkapi tugas pengawasan yang diberikan oleh komisaris, sebab kepatuhan syariah semakin penting untuk dilakukan karena adanya permintaan dari nasabah agar bersifat inovatif dan berorientasi bisnis dalam menawarkan instrumen dan produk baru serta untuk memastikan kepatuhan terhadap hukum Islam.

Dalam ajaran Islam, kelima prinsip-prinsip pokok GCG $^{1} \mathrm{di}$ atas sesuai dengan norma dan nilai islami dalam aktivitas dan

1 Peraturan Bank Indonesia No.11/33/PBI/2009 Tentang Pelaksanaan Good Corporate Governance Bank Umum. Tugas dan tanggungjawab dewan direksi/direktur adalah sebagi berikut: (1) Direksi bertanggungjawab penuh atas pelaksanaan pengelolaan BUS 
kehidupan seorang Muslim. Islam sangat intens mengajarkan diterapkannya prinsip 'adalah (keadilan), tawazun (keseimbangan), mas'ūliyah (akuntabilitas), akhlāq (moral), siddìq (kejujuran), amānah (pemenuhan kepercayaan), fațanah (kecerdasan), tabligh (transparansi, keterbukaan), hurriyyah (independensi dan kebebasan yang bertanggung jawab), ị̣sān (profesional), wasațan (kewajaran), ghīrah (militansi syariah), idārah (pengelolaan), khilāfah (kepemimpinan), 'aqīdah (keimanan), ijābiyyah (berfikir positif), raqabah (pengawasan), qirā'ah dan ilāh (organisasi yang terus belajar dan selalu melakukan perbaikan). Tuntutan pemenuhan prinsip syariah (shariah compliance), bila dirujuk pada sejarah perkembangan bank syariah, alasan pokok dari keberadaan perbankan syariah adalah munculnya kesadaran masyarakat Muslim yang ingin menjalankan seluruh aktivitas keuangannya berdasarkan al-Qur'an dan Sunnah. Oleh karena itulah jaminan mengenai pemenuhan terhadap syariah (shariah compliance) dari seluruh aktivitas pengelolaan dana nasabah oleh bank syariah merupakan hal yang sangat penting dalam kegiatan usaha bank syariah.

Dari keenam prinsip, shariah compliance merupakan indikator yang paling berpengaruh dalam implementasi shariah governance sehingga dalam penerapannya, para pengelola bank syariah harus merujuk kepada kepatuhan pada prinsip-prinsip dan nilai-nilai syariah, karena perbankan syariah merupakan lembaga intermediasi yang amat membutuhkan kepercayaaan masyarakat agar dipercaya

berdasarkan prinsip kehati-hatian dan prinsip syariah; serta(2) Direksi wajib mengelola Bank Umum Syariah sesuai dengan kewenangan dan tanggungjawabnya sebagaimana diatur dalam anggaran dasar Bank Umum Syariah dan peraturan perundang-undangan yang berlaku. 
seluruh stakeholders. Disinilah pentingnya peranan Dewan Pengawas Syariah (DPS) dalam menjaga shariah compliance yang berkaitan erat dengan pengelolaan perusahaan dari sisi kebenaran syariah, dan hal ini akan menjadi sangat penting ketika perusahaan akan mengeluarkan produk-produk perbankannya. Sehingga bisa kita simpulkan, selain tata kelola yang baik dari sisi manajemen perusahaan, tata kelola pengawasan dan pengembangan yang dilakukan oleh DPS menjadi tolak ukur mendasar dalam kesuksesan penerapan shariah governance pada bank syariah. Pelanggaran shariah compliance yang dibiarkan DPS atau luput dari pengawasan DPS, jelas akan merusak citra dan kredibilitas bank syariah di mata masyarakat, sehingga dapat menurunkan kepercayaan masyarakat kepada bank syariah.

Untuk itulah peran DPS di bank syariah harus benar-benar dioptimalkan, kualifikasi menjadi DPS harus diperketat, dan formalisasi perannya harus diwujudkan di bank syariah tersebut. Peran DPS tidak optimal dalam melakukan pengawasan syariah terhadap praktik syariah yang berakibat pada pelanggaran shariah compliance, maka citra dan kredibilitas bank syariah di mata masyarakat menjadi negatif, sehingga dapat menurunkan kepercayaan masyarakat kepada bank syariah. Sehingga implementasi shariah governance akan berpengaruh terhadap kepercayaan pada bank syariah, semakin baik implementasi shariah governance yang dilakukan bank syariah semakin baik reputasi bank syariah dan pada akhirnya akan meningkatkan kepercayaan nasabah pada bank syariah.

Penelitian yang dilakukan Muhammad Noer tentang implementasi prinsip syariah pada perbankan syariah menunjukkan 
terdapat perbedaan pemahaman kesesuaian akad pembiayaan antara personel bank syariah dengan nasabah secara siginifikan. Dalam penelitian Rahman praktek penerapan prinsip syariah belum dilaksanakan secara kaffah hal ini mempengaruhi kepercayaan dan loyalitas masyarakat terhadap bank syariah. Menurut hasil penelitian IRTI menunjukkan pelaksanaan good corporate governance belum terlaksana dengan baik di perbankan syariah pada berbagai negara. Penerapan GCG terbukti di dalam penelitian dibeberapa lembaga keuangan syariah di dunia Muslim dapat meningkatkan kepercayaan masyarakat kepada bank syariah. Nasabah memutuskan untuk tetap mempertahankan bank syariah berkaitan dengan masalah keimanan dan keyakinan terhadap pengharaman riba bagi umat Islam.

Dalam pokok-pokok hasil penelitian Bank Indonesia menyatakan bahwa nasabah yang menggunakan jasa bank syariah, sebagian memiliki kecenderungan untuk berhenti menjadi nasabah antara lain karena keraguan akan konsistensi penerapan prinsip syariah. Kepatuhan dan kesesuaian bank terhadap prinsip syariah sering dipertanyakan oleh para nasabah. Secara implisit hal tersebut menunjukkan bahwa praktik perbankan syariah selama ini kurang memperhatikan prinsip-prinsip syariah, salah satu penyebab rendahnya kepercayaan terhadap bank syariah. Kepercayaan menjadi salah satu faktor penting dalam membangun hubungan kemitraan antar bank syariah dengan nasabah. Tanpa adanya kepercayaan, suatu hubungan kerjasama tidak mungkin mampu bertahan dalam jangka waktu lama. Kepercayaan timbul sebagai hasil dari kehandalan dan integritas mitra yang ditunjukkan melalui 
berbagai sikap seperti konsistensi, kompeten, adil, bertanggung jawab, suka menolong dan memiliki kepedulian.

Ketaatan terhadap syariah merupakan faktor utama nasabah menjalin kemitraan dengan bank syariah, oleh karena itu nasabah memutuskan untuk tetap mempertahankan bank syariah berkaitan dengan masalah keyakinan terhadap ketaatan bank syariah pada prinsip-prinsip syariah dalam menjalankan usahanya. Dalam pokokpokok hasil penelitian Bank Indonesia menyatakan bahwa nasabah yang menggunakan jasa bank syariah, sebagian memiliki kecenderungan untuk berhenti menjadi nasabah antara lain karena keraguan terhadap konsistensi penerapan prinsip syariah. Kepatuhan dan kesesuaian bank terhadap prinsip syariah sering dipertanyakan oleh para nasabah. Secara implisit hal tersebut menunjukkan bahwa praktik perbankan syariah selama ini kurang memperhatikan prinsip-prinsip syariah, salah satu penyebab rendahnya kepercayaan nasabah pada bank syariah. Peningkatan kepercayaan pada bank syariah merupakan salah satu indikator kinerja bank syariah dalam meningkatkan market share-nya, sehingga dapat disimpulkan bahwa dengan mengimplementasikan shariah governance akan berpengaruh terhadap kepercayaan nasabah. Meningkatnya kepercayaan dalam jangka panjang akan meningkatkan loyalitas nasabah yang pada akhirnya akan meningkatkan market share bank syariah. (Rahman El-Junusi, 2009)

Dalam implementasi shariah governance beberapa hal yang harus dipertimbangkan oleh bank syariah dalam rangka meningkatkan kepercayaan pada bank syariah: (1) Shariah compliance merupakan indikator yang sangat mempengaruhi kepercayaan bank syariah, sehingga bank syariah harus hati-hati menjalankan 
operasionalnya, namun dari beberapa indikator shariah compliance peran DPS merupakan indikator yang paling kecil menjelaskan shariah compliance. Persepsi responden terhadap peran DPS masih dirasakan belum optimal, karena masih ada bank syariah yang menjalankan operasionalnya mengabaikan prinsip-prinsip. Oleh karena itu bank syariah harus meningkatkan profesionalitas dan kapabilitas DPS dalam menjalankan tugas dalam menjaga ketaatan terhadap syariah; (2) Meningkatkan responsibility, karena indikator ini merupakan indikator yang paling kecil dalam menjelaskan shariah governance. Dengan meningkatkan pelayanan, respon terhadap nasabah dan lingkungan akan meningkatkan responsibility bank syariah yang pada akhirnya akan meningkatkan kepercayaan pada bank syariah; (3) Meningkatkan fairness, dengan memberi kesempatan pada nasabah menyampaikan keluhan, serta menindaklanjuti keluhan dengan cepat dan tepat serta kepentingan dan kebutuhan layanan harus mendapat perhatian bank syariah. Meningkatnya fairness akan meningkatkan kepercayaan pada bank syariah, pada akhirnya akan meningkatkan market share bank syariah dan (4) Meningkatkan tranparansi dan akuntabilitas melalui kemudahan akses informasi, penyampaian informasi layanan yang jelas, tepat dan akurat sesuai kebutuhan nasabah serta kebijakankebijakan yang diambil mempertimbangkan kepentingan nasabah dan konsisten dengan Undang-undang yang berlaku. Itu semua dapat meningkatkan kepercayaan pada bank syariah.

Untuk melakukan efektivitas dalam kepatuhan syariah, maka diperlukan beberapa upaya. Pertama, protektif, yaitu memastikan terciptanya ketaatan kebijakan, ketentuan, dan peraturan yang berlaku melalui analisis di bidang keuangan, akuntansi, operasional 
dan kegiatan lainnya dalam pemeriksaan maupun pengawasan. Kedua, konstruktif, yaitu menjaga tingkat kehematan penggunaan sumberdaya dan efektivitas hasil yang maksimal melalui saran perbaikan dan informasi obyektif untuk melakukan review pada semua tingkatan manajemen. Ketiga, konsultatif, yaitu memberikan rekomendasi yang bermanfaat bagi seluruh manajemen sebagai penyempurnaan kebijakan dalam rangka mencapai tujuan organisasi melalui identifikasi segala kemungkinan risiko dan penyimpangan untuk memperbaiki dan meningkatkan efisiensi penggunaan sumberdaya dan dana, sehingga penyimpangan dapat terdeteksi. (Sepky Mardian, 2015).

\section{PENUTUP}

Berdasarkan uraikan diatas, dapat diperoleh deskripsi bahwa penerapan kepatuhan syariah pada bank syariah terutama persoalan market share dan penurunan kepatuhan terhadap prinsip-prinsip syariah, idealnya harus diawali dengan mengimplementasikan shariah governance sehingga akan berdampak pada peningkatan kepercayaan pada bank syariah yang pada akhirnya akan meningkatkan market share bank syariah. Tujuannya antara lain: (1) Memberikan pemahaman bagi regulator dan pelaku industri perbankan syariah tentang implementasi shariah governance pada bank syariah serta implikasinya terhadap kepercayaan nasabah; (2) Memberikan dasar pertimbangan dalam rangka perumusan langkah strategi untuk menyempurnakan kebijakan pengembangan oleh Bank Indonesia maupun strategi penguasaan pasar oleh masing-masing bank syariah. 
Lebih lanjut sebagai upaya membangun budaya kepatuhan syariah pada bank syariah seyogyanya dapat melakukan langkah-langkah untuk mendukung terciptanya budaya kepatuhan, di antaranya: (1) penerbitan piagam kepatuhan, yakni dokumen kepatuhan yang bersifat strategis dan berisi panduan, peraturan, kaidah dan kebijakan bank yang wajib dipatuhi oleh seluruh jajaran bank syariah; (2) penerbitan kebijakan kepatuhan, yakni rangkaian asas yang menjadi garis besar dan dasar pelaksanaan fungsi kepatuhan bank; (3) sistem kepatuhan bank, yakni perangkat pendukung yang telah ditetapkan oleh bank dalam bentuk standar manual kerja maupun yang berbasis teknologi untuk mendukung pelaksanaan kepatuhan bank syariah. Sistem kepatuhan bank syariah meliputi: standar prosedur kerja, ketersediaan unit pelaksana fungsi kepatuhan bank dan tersedianya sistem informasi kepatuhan atau media pendukung pelaksana kepatuhan bank syariah; dan (4) kerangka berpikir, yakni cara pandang dan perilaku jajaran bank dalam menjalankan tugas sehari hari untuk senantiasa mengedepankan prudensialitas, ketaatan pada kepatuhan dan menghindarkan penyimpangan, tidak mengorbankan kualitas dengan kuantitas, tidak menyalahi wewenang, tidak melemahkan pengendalian internal dan tidak mengabaikan risiko kepatuhan dengan eksepsi yang berlebihan.

Oleh karena itu pada masa yang akan datang perlu pengungkapan secara penuh informasi kepatuhan syariah dari laporan/opini DPS bank syariah. Jika kita melihat dan membaca laporan bank syariah masih bersifat global dan kurang menyajikan informasi yang detail. Untuk meningkatkan kualitas laporannya, bank syariah perlu menyusun laporan/opini DPS bank syariah dengan menggunakan konsep pengungkapan secara penuh (full disclosure principles) sehingga kepatuhan syariah bukan lagi menjadi misteri bagi masyarakat atau stakeholder bank syariah tapi bisa diterapkan secara komprehensif. 


\section{DAFTAR PUSTAKA}

Ansori. (2001) "Pengungkapan Sharia Compliance dan Kepatuhan Bank Syariah terhadap Prinsip Syariah", dalam Jurnal Dinamika Akuntasi, 3, 2, Maret .

Ardhaningsih dan Septian G. (2012). “Shariah Compliance Akad Murabahah pada BRI Syariah KCI Surabaya Gubeng". Skripsi, Universitas Airlangga, Surabaya.

Arifin, Z. (2009). Dasar-dasar Manajemen Bank Syariah.Tangerang: Aztera Publisher.

AAOIFI. (2003). Accounting and Auditing Standards for Islamic Financial Institution. Bahrain.

Antonio, S. (2001). Bank Syariah bagi Banker dan Praktisi Keuangan, Jakarta: Tazkia Institute.

Chapra, M.U. and Ahmed, H. (2002) "Corporate Governance in Islamic Financial Institutions," Occasional Paper No. 6, Jeddah: Islamic Research\&Training Institute/Islamic Development Bank.

Chapra, M. U dan Ahmed, H. (2008). Corporate Governance Lembaga Keuangan Syariah, Jakarta: Bumi Aksara.

El-Junusi, R. (2009). “Pengaruh Atribut Produk Islam, Komitmen Agama, Kualitas Jasa dan Kepercayaan terhadap Kepuasan dan Loyalitas Nasabah Bank Syariah (Bank Muamalat Kota Semarang)", paper dipublikasikan pada acara The 9 th Annual Conference on Islamic Studies (ACIS), Surakarta.

Ilhami, H. (2009). "Pertanggungjawaban Dewan Pengurus Syariah Sebagai Otoritas Pengawas Kepatuhan Syariah Bagi Bank Syariah", Jurnal Mimbar Hukum, 21, 3.

Iqbal, Zr dan Mirakhor, A. (2008). Pengantar Keuangan Islam: Teori dan Praktek, terj. Oleh A.K. Anwar, Jakarta: Prenada Media Group.

Muhammad Noer, "Implementasi Prinsip Syariah pada Bank Syariah di Kota Semarang," Fokus Ekonomi, 6, 1, Unnes, Semarang. 
Wulpiah

Mardian, S. (2015). “Tingkat Kepatuhan Syariah di Lembaga Keuangan Syariah", Jurnal Akuntansi dan Keuangan Islam, 3, 1, Program Studi Akuntansi Syariah Sekolah Tinggi Ekonomi Islam SEBI.

Noer, M. (2007). “Implementasi Prinsip Syari’ah pada Bank Syari'ah di Kota Semarang," Jurnal Fokus Ekonomi, 6, 1, Unnes, Semarang.

Peraturan Bank Indonesia No.11/33/PBI/2009 Tentang Pelaksanaan Good Corporate Governance Bank Umum. Tugas dan tanggungjawab dewan direksi/direktur adalah sebagi berikut: (1) Direksi bertanggungjawab penuh atas pelaksanaan pengelolaan BUS berdasarkan prinsip kehatihatian dan prinsip syariah; serta (2) Direksi wajib mengelola Bank Umum Syariah sesuai dengan kewenangan dan tanggungjawabnya sebagaimana diatur dalam anggaran dasar Bank Umum Syariah dan peraturan perundang-undangan yang berlaku.

Saramawati, D. dan Lubis, T. (2014). "Analisis Pengungkapan Syariah Compliance dalam Pelaksanaan Good Corporate Governance Bank Syariah di Indonesia", Jurnal Akuntansi dan Keuangan Islam, 2, 2.

Sukardi, B. (2011). Kepatuhan Syariah (Syari'ah Compliance) dan Inovasi Produk Bank Syariah di Indonesia. IAIN Surakarta.

Sutedi, A. (2009). Perbankan Syariah, Tinjauan dan Beberapa Segi Hukum. Jakarta: Ghalia Indonesia.

Waluyo, A. (2016). “Kepatuhan Bank Syariah terhadap Fatwa Dewan Syariah Nasional Pasca Transformasi dalam Hukum Positif", INFERENSI, Jurnal Penelitian Sosial Keagamaan, Institut Agama Islam Negeri (IAIN), 10, 2. 